\title{
6. MULTIBEAM ECHO-SOUNDING BATHYMETRY OF EL JADIDA PLATEAU AND ESCARPMENT, MAZAGAN, WEST MOROCCO ${ }^{1}$
}

\author{
J. M. Auzende and S. Monti, Centre Océanologique de Bretagne \\ and \\ E. Ruellan, Université de Bretagne Occidentale ${ }^{2}$
}

\section{INTRODUCTION}

The Moroccan continental margin located west of Casablanca displays features which have greatly interested the international geophysical and geological community, and which are in particular characterized by the El Jadida Plateau and Escarpment (Mazagan; see Fig. 1) which offer a unique opportunity for studying the first deposits accompanying the early subsidence of the margins of the oldest part of the Atlantic Ocean. Many cruises to this area have used standard techniques of investigation, [including] single or multichannel seismic reflection, magnetics, gravity, and coring: examples include Vema cruises $23,27,29,30$, and 2 by the LamontDoherty Geological Observatory, Meteor cruises 25, 39, 46 , and 53 and Valdivia cruise 79 by the Bundesanstalt für Geowissenschaften und Rohstoffe (BGR), and those of Jean Charcot, and the NESTLANTE I, GIBRACO, and ALBATLANTE cruises by the Centre National pour l'Exploitation des Océans (CNEXO). One of the most important goals of these cruises was to locate appropriate drilling sites for Leg 50 (Lancelot, Winterer, et al., 1980) and Leg 79 of the Deep Sea Drilling Project. Wide-angle bathymetric surveys obtained during the geophysical surveys made by these cruises have provided data for different maps, particularly those by the BGR in 1980 (Hinz et al., 1982) and by J. R. Vanney (unpublished map at 1:100,000 incorporating Gebco data as well as those from various oceanographic cruises; pers. comm., 1979).

The interesting geology of El Jadida Escarpment led to two projects for exploration of the escarpment by submersible-the first, proposed by Y. Lancelot, presented to the CNEXO Submersible Committee in 1978 and the second presented to the same committee in 1980 by U. von Rad of the BGR. The committee supported and encouraged the creation of a French-German team to carry out the research. The result was the CYAMAZ cruise of the Cyana SP 3000 submersible (see CYAMAZ group, this volume).

The diving program necessitated a more detailed bathymetric survey than had hitherto been made. In 1977,

\footnotetext{
${ }^{1}$ Hinz, K., Winterer, E. L., et al., Init. Repts. DSDP, 79: Washington (U.S. Govt. Printing Office).

Addresses: (Auzende, Monti) Centre Oceánologique de Bretagne (CNEXO), B. P. 337, 29273 Brest Cedex, France; (Ruellan), Université de Bretagne Occidentale, G.I.S. Océanologie et Geodynamique, Avenue Le Gorgeu, 29283 Brest Cedex, France.
}

CNEXO had equipped the Jean Charcot with the Seabeam, a multibeam echo sounder which, unlike the standard echo sounders, which yield only a single sounding trace, scans a seafloor corridor corresponding to threequarters of the water depth and provides detailed contours from which the slopes and the directions of the structures can be readily visualized.

\section{SEAZAGAN CRUISE}

The objective of the Jean Charcot SEAZAGAN cruise (27 May-10 June 1982) was complete bathymetric coverage by Seabeam of a part of the Plateau and of the El Jadida Escarpment down to its junction with the Seine Abyssal Plain at $\sim 4200 \mathrm{~m}$ water depth.

To this end, 39 Seabeam lines were made (Fig. 2) during eight days of site survey and a $5000-\mathrm{km}^{2}$ area was covered. Profiles were made parallel to the isobaths to ensure optimum efficiency of the survey. The spacing between each two tracks was $0.6 \times$ depth, and the average speed of the ship was 10 knots.

The Seabeam has 16 beams of $22 / 3^{\circ}$ width each. The system is exploited in real time using a plotter flatbed and can be replaced after navigational corrections have been made (Renard and Allenou, 1979; Desnoes, 1979). A speed of $1,500 \mathrm{~m} / \mathrm{s}$ was used for sound propagation in the water. During the SEAZAGAN cruise, we had no radioelectric navigational system at our disposal and the survey was made with a standard satellite navigation system. Two or three good satellite fixes were obtained on each profile, giving us very good control.

Three 1:50,000 maps were drawn aboard the Jean Charcoat with a $20-\mathrm{m}$ contour interval. Reductions of these appear as back pocket Figure 3. In addition, a 1:100,000 map drawn after the cruise with a contour interval of 50 $\mathrm{m}$ appears as back pocket Figure 4 (Auzende et al., 1983). Finally, maps of five sites chosen as diving sites were drawn at a scale of 1:10,000 (not shown).

\section{FEATURES OF THE MAP}

The objective of this chapter is not to give a detailed geomorphological description of the mapped area (later studies will do so), but to give a general outline of the zones covered by our map. Schematically, the El Jadida (Mazagan) Plateau and Escarpment form a crescentshaped promontory with its convex side toward the Seine abyssal plain west of Casablanca. We can distinguish three zones: the El Jadida Plateau, the Escarpment, and an apron forming the junction with the Abyssal Plain. 


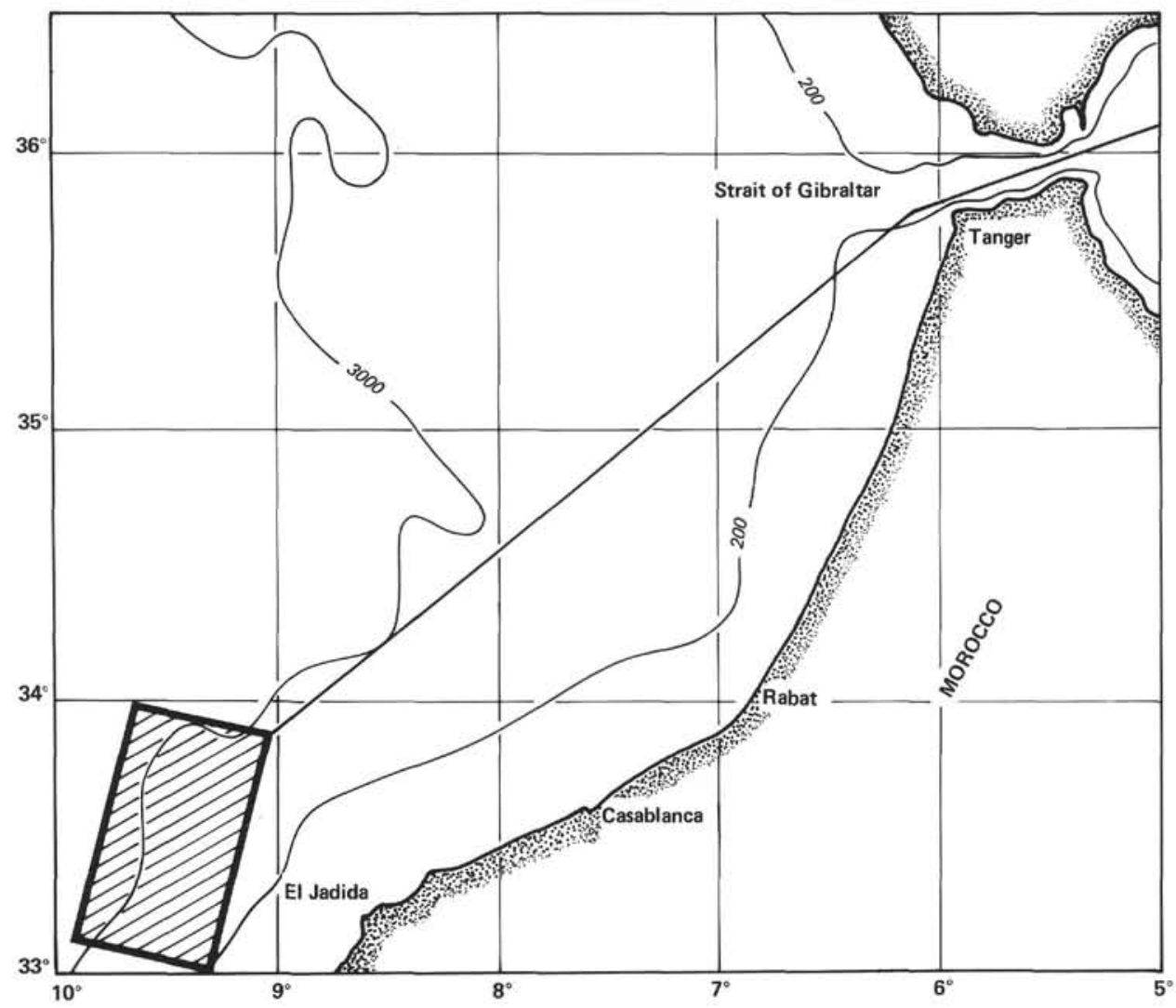

Figure 1. Location of SEAZAGAN cruise on the Moroccan margin.

\section{The Plateau}

Between the shore and about $1300 \mathrm{~m}$ water depth, the plateau slopes very gently toward the west to the edge of the Escarpment. Toward the northwest, the plateau is perceptibly broader, and the flat area spreads to the 2000 $\mathrm{m}$ isobath. Obviously, this plateau is structurally controlled by northeast-southwest features. In the southern part is a promontory oriented north-south and very probably controlled by a substratum horst. This promontory detaches eastward a small reentrant to the $750-\mathrm{m}$ isobath that is also controlled by northeast-southwest directions.

\section{The Escarpment}

Very steep slopes are observed between 1300 and 3000 $\mathrm{m}$ in the central and southern parts. On some of these profiles, the average slope is between $45^{\circ}$ and $75^{\circ}$. The main cliff in these areas is in most cases between 1300 and $2000 \mathrm{~m}$ high. Some irregularly wide steps appear below, representing the vast areas of talus making up the apron. Those steps are more accentuated in the southern part of the escarpment, between $33^{\circ} 10$ and $33^{\circ} 20 \mathrm{~N}$.

\section{The Apron}

A broad apron forming the junction with the Seine Abyssal Plain lies at the foot of the escarpment, $3000 \mathrm{~m}$ below. The morphology of this apron is similar to that of the talus areas at the foot of the slopes, and it is pos- sible to observe some cleavages roughly parallel to the highest slope lines. The apron is particularly prominent in the south, where it contains a series of canyons oriented west-northwest to east-southeast, the most important of which is the El Jadida Canyon. In the north, the apron is also very wide; it is broken up by high zones showing differences in level of a few meters, obviously controlled by faults oriented southwest-northeast and north-south. The high zone on the northwestern side of the map is much more circular and could be associated with a diapiric structure.

The presentation of these maps is only preliminary. Future work using all the seismic reflection and bathymetric data as well as observations with the submersible (see CYAMAZ group, this volume) should allow us to establish a connection between morphology and the geological data (carbonate platform, consolidated sediments, soft sediments) constituting the El Jadida Plateau and Escarpment.

\section{ACKNOWLEDGMENTS}

We thank Yann Keranflech, Captain of Jean Charcot, his crew, and the scientific party of the SEAZAGAN cruise for their invaluable contributions. We thank J. R. Vanney for providing a copy of his $1: 100,000$ map of El Jadida Plateau and Escarpment before the SEAZAGAN cruise. This chapter is Contribution No. 804 of the Centre Océanologique de Bretagne.

\section{REFERENCES}

Auzende, J. M., Monti, S., and Ruellan, E., 1983. Bathymetric Maps of the El Jadida Escarpment. CNEXO Publication. 
Desnoes, Y., 1979. Contourage des données du sondeur multifaisceaux "Seabeam" en temps différé. Unpublished CNEXO report, March 1979.

Hinz, K., Winterer, E. L., Baumgartner, P. O., Bradshaw, M. J., Channel, J. E. T., Jaffrezo, M., Jansa, L. F., Leckie, R. M., Moore, J. N., Rullkötter, J., Schaftenaar, C., Steiger, T. H., Vuchev, Y., and Wiegand, G. E., 1982. Preliminary results from DSDP Leg 79 seaward of the Mazagan Plateau off Central Morocco. In von Rad, U., Hinz, K., Sarnthein, M., and Seibold, E. (Eds.), Geology of the Northwest African Continental Margin; Berlin (SpringerVerlag), pp. 23-33.

Lancelot, Y., Winterer, E. L., et al., 1980. Init. Repts. DSDP, 50: Washington (U.S. Govt. Printing Office).

Renard, V., and Allenou, J. P., 1979. The multibeam echosounder Seabeam in Jean Charcot. Hydrog. Int. Rev. Monaco, 56:35-71.

Date of Initial Receipt: March 3, 1983

Date of Acceptance: April 29, 1983

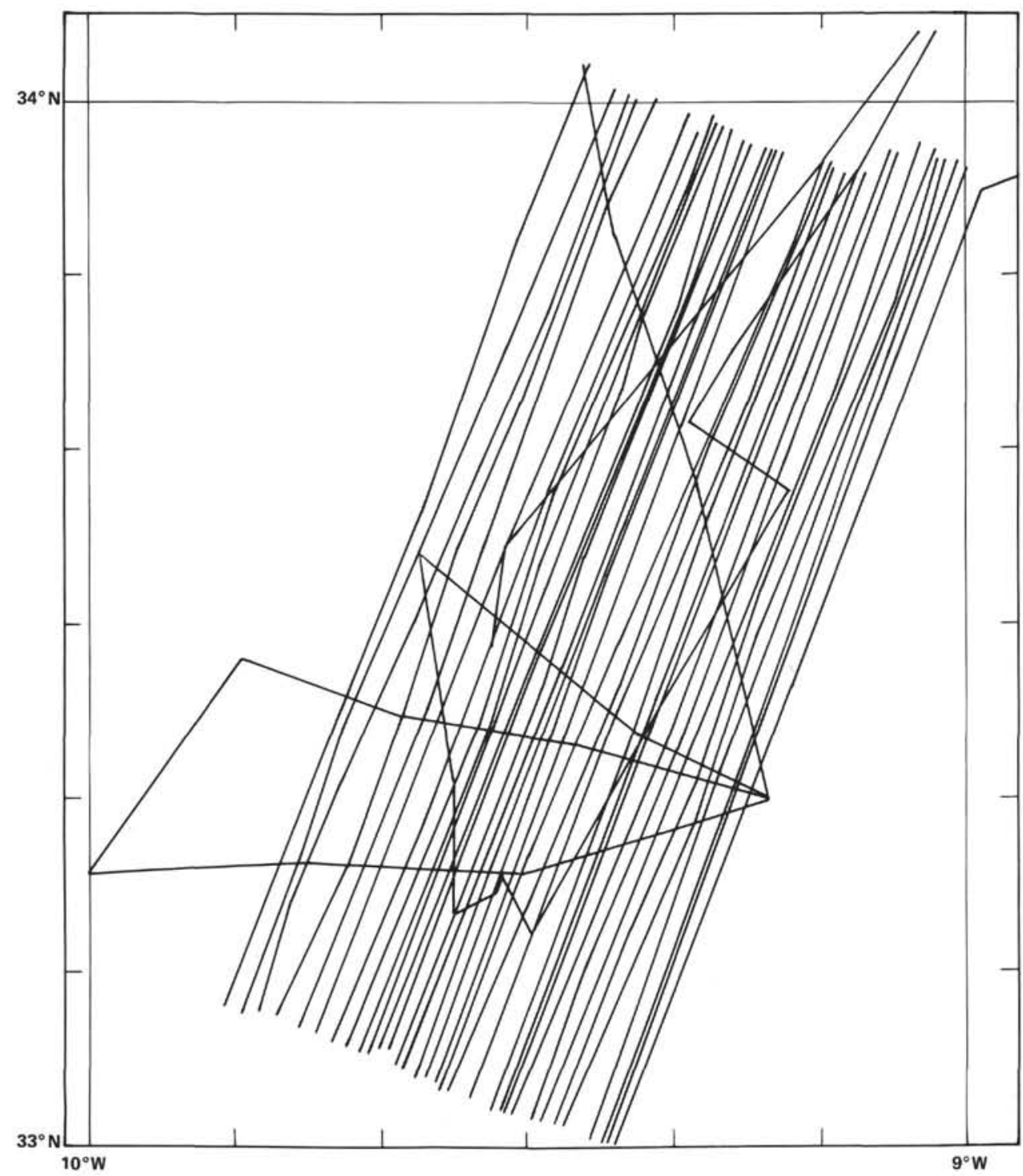

Figure 2. Location of Seabeam profiles. 